\title{
The Peace Treaty of TARTU: The Postcolonial Situation 100 Years LATER ${ }^{\star}$
}

\author{
Kaarel Piirimäe
}

This special issue marks the $100^{\text {th }}$ anniversary of the Peace of Tartu signed by the Soviet and Estonian governments on 2 February 1920. In this introduction, I will briefly discuss the importance of the Tartu Peace Treaty for Estonian national identity, and its impact on Estonia's relations with the Russian Federation. I will employ the perspective of colonial history (not postcolonial theory) to briefly consider possibilities for overcoming or at least alleviating the Estonian-Russian disagreement over the Tartu Peace Treaty that has lain at the heart of Estonian-Russian tensions since the 1990 .

This special issue is partly the result of a conference held in February of 2020 in Tartu at the behest of the Ministry of Foreign Affairs of Estonia to mark the anniversary of the Peace of Tartu. At that conference, the Estonian Foreign Minister took the opportunity to present the official Estonian interpretation of the meaning of the Tartu Peace Treaty, and just before the event, the Foreign Ministry of the Russian Federation also reiterated the Russian position. ${ }^{1}$ Despite this clash of official histories at the very outset, the conference itself was thoroughly academic, discussing the Tartu Peace Treaty from historical, legal, and IR-studies perspectives. This showed that national anniversaries can be occasions not only for governments to confirm their official narratives but also for more imaginative thinking that challenges those same narratives. ${ }^{2}$

\footnotetext{
* Research has been supported by the Estonian Science Foundation (PRG 942), the Academy of Finland (BALTRANS) and the Fulbright Program.

1 "Välisminister Reinsalu: Tartu rahuleping kehtib", https://vm.ee/et/uudised/valisminister-reinsalu-tartu-rahuleping-kehtib; "O prazdnovanii v Estonii 10o-letiia Tartuskogo dogovora”. Brifing ofitsial'nogo predstavitelia MID Rossii M. V.Zakharovoi, Moscow, 30 January 2020, https://www.mid.ru/brifingi/-/asset_publisher/MCZ7HQuMdqBY/ content/id/4014412\#O (21 January 2021).

2 Alongside historians David Feest and Konstantin Khudoley, Kimmo Rentola of the University of Helsinki presented a paper at the Tartu Peace Treaty conference, see programme: https://vm.ee/sites/default/files/Estonia_for_UN/Rasmus/tartu_rahu_100_ kava_est.pdf (21 January 2021).
} 
What we saw at the start of the conference, with Estonian and Russian spokespersons reiterating their official lines, was not at all surprising. All communities have dominant narratives about core aspects of the community's past, giving meaning to the present and opening certain vistas for the future. In fact, those narratives help constitute the community in the first place. These core narratives - also referred to as 'basic discourse', 'master narrative', etc. ${ }^{3}$ - are always contested between rivalling social groups within the community. Nevertheless, in broad terms, the master narrative remains quite stable, enabling it to give coherence to the community's identity. Moreover, at the level of the state's interaction with other societies in the world community, the master narrative must be both coherent and consistent. The political scientist Hussein Banai has recapitulated this most succinctly: 'State-sanctioned diplomacy [...] is in large measure the practice of mediating state-sanctioned histories.'

By using the term 'mediating', Banai takes a normative view of diplomacy, seeing it as a tool for mediating - and therefore ameliorating and ideally resolving - conflicts between countries resulting from conflicting interpretations of history. One may agree with Banai at this point, as classic definitions of diplomacy all point toward the civilising and mediating aspects of the tradition of diplomacy. ${ }^{5}$ The official histories that diplomats represent invariably include stories about other nations, thus these narratives interact and collide with the official histories of other countries. Sovereign diplomacy is, therefore, the practice of communicating a country's official view of the past and negotiating over the points on which other countries disagree.

In order to be able to mediate, diplomacy must be imaginative about one's own historical master narrative. It needs to engage with public imaginations of the past that offer alternative points of view. 'The diplomat's function, as an intermediary between alien public imaginations, is to relentlessly demystify and debunk seemingly monolithic representations of self

3 Felix Berenskoetter, "Parameters of a national biography", European journal of international relations 1 (20) (2014), 262-288; Hayden White, "The value of narrativity in the representation of reality", Critical inquiry 1 (7) (1980), 5-27; Consuelo Cruz, "Identity and persuasion: How nations remember their pasts and make their futures", World politics (2000), 275-312; Francesca Polletta, “It was like a fever..." narrative and identity in social protest', Social problems 2 (45) (1998), 137-159.

4 Hussein Banai, "Diplomatic imaginations: mediating estrangement in world society", Cambridge Review of International Affairs 3 (27) (2014), 459-474.

5 Harold Nicolson, Diplomacy (London: Oxford University Press, 1939); Hedley Bull, The Anarchical Society: A Study of Order in World Politics (London: Macmillan, 1977). 
and other,' argues Banai. ${ }^{6}$ Conferences like the one in February of 2020, or journal special issues like this one, may prove useful in providing material for state actors to rethink official narratives, or even negotiating briefs.

The Tartu Peace Treaty of 1920 is an example of an historic event that causes a direct clash between the state-sanctioned histories of two countries, and underlines many of the problems that the countries face in their diplomacy. Because the Tartu Peace Treaty lies at the heart of Estonia's master narrative, and therefore of state identity, and apparently also concerns some core ideas in the Russian version of the past, the dispute over the treaty has become a test-case for the development of Estonian-Russian relations. Closing the gap between the narratives would also signal the closing of the gap in relations between the two neighbours.

The Tartu Peace Treaty is central to Estonia's understanding of itself as heir - in both legal and cultural terms - to the Republic established in 1918, recognised by Soviet Russia in the Tartu Peace Treaty in 1920, occupied and annexed by the latter in 1940, and restored as legally identical to the pre-war Republic in 1991. ${ }^{7}$ The Russian Federation, on the other hand, argues that all treaties between Russia and Estonia, including the Tartu Peace Treaty, were terminated by Estonia's accession to the USSR as a Soviet Socialist Republic in 1940. Present-day Estonia, the Russian government is convinced, is not identical to the Estonia created in 1918, but rather is a new legal entity that came into being after the secession of Soviet Estonia from the USSR in 1991. Estonian-Russian relations, Moscow's spokespersons argue, are based on the Treaty on Basic Principles of Interstate Relations signed by the Estonian and Russian governments on 12 January 1991, and not on the Tartu Peace Treaty that has value only as a historical curiosity. ${ }^{8}$

There is a paradox in Russia's position, since Russia states that Estonia, which it regards as a former part of the USSR, is an entirely new legal entity, whereas Russia, also formerly part of the USSR, is entitled to be the legal heir of the Soviet Union. ${ }^{9}$ There is also an inconsistency, because in the Basic Principles Treaty of 1991, the Government of Boris Yeltsin

\footnotetext{
6 Banai, "Diplomatic imaginations".

7 Eiki Berg, "Some unintended consequences of geopolitical reasoning in post-Soviet Estonia: Texts and policy streams, maps and cartoons", Geopolitics 1 (8) (2003), 101-120; Tanel Kerikmäe, Hannes Vallikivi, "State Continuity in the Light of Estonian Treaties Concluded before World War II", Juridica Int'l 5 (2000), 30-39; Peter Van Elsuwege, "State continuity and its consequences: the case of the Baltic States", LJIL 2 (16) (2003), 377-388.

8 V. Loshchinin, “The Baltic States: The Situation Is Often Discouraging”, International Affairs 1 (42) (1996), 48-54. For a sympathetic view from Russia, see: Georgy Kunadze, “Opinion. Why provoke conflicts?”, The New Times, 8 (2005), 49.

9 "O prazdnovanii v Estonii 10o-letiia".
} 
recognised the validity of the Tartu Peace Treaty by referring, in the preamble, to the declarations of the Supreme Soviet of Estonia of 30 March 1990 and 7 August 1990. The Estonian declaration of 30 March 1990 reiterated that the acts of 1940 were null and void in terms of international law. The declaration of 7 August 1990 specifically stated that relations between Estonia and the USSR would be based on treaties that were still valid, that is the Peace Treaty of Tartu and other treaties concluded between 1920 and 1940. Russia, which in 1991 was still part of the USSR, was opposed to mentioning the Tartu Peace in the main text of the Basic Principles Treaty but was accommodating toward the Estonian position by consenting to refer to the Treaty indirectly. Importantly, Russia's legislature chose to ratify the Basic Principles Treaty on 26 December 1991, that is on the same day that the Soviet Union ceased to exist and Russia became its successor. It is interesting to note in this connection that in 1990-1991, Estonia negotiated not only with the Russian but also the Soviet government, and just before the attempted coup d'état in August of 1991, Gorbachev's government also showed sympathy toward the Estonian position. ${ }^{10}$

What makes the Tartu Peace Treaty particularly attractive from the Estonian point of view is Article Two of the treaty, which reads as follows:

On the basis of the right of all peoples to freely decide their destinies, and even to separate themselves completely from the state of which they form a part, a right proclaimed by the Federal Socialist Republic of Soviet Russia, Russia unreservedly recognises the independence and autonomy of the State of Estonia and renounces voluntarily and forever all rights of sovereignty formerly held by Russia over the Estonian people and territory of Estonia by virtue of the former legal situation, and by virtue of international treaties, which, in respect of such rights, shall henceforth lose their force. No obligation to Russia devolves upon the Estonian people and territory from the fact that Estonia was formerly part of Russia. ${ }^{11}$

The wording of that article leaves little doubt that in 1920, Russia unconditionally relinquished all claims to Estonia. Seen in this light, Russia acknowledged that colonisation of the Estonian territory had come to an end; moreover, it stated that the basis for decolonisation was the right of peoples

10 Ülo Nugis, “Minu viimased läbirääkimised”, Luup, 16 (1998), 52, cited by Juhan Värk, "Venemaa positiivse hõlvamise poliitika ja teiste välispoliitiliste liinide mõjud Eesti-Vene suhetele aastail 1991-2011”, Doctoral dissertation (Tallinn: Tallinn Technical University, 2012).

11 "Peace Treaty of Tartu, 2 February 1920", League of Nations Treaty Series. Vol. XI, $51-52$. 
to self-determination - a right that was not yet part of international law but had been declared by the Bolshevik government to be the basis upon which a new order would be created in the former Russian imperial space. This suited the Estonian government, which at the time had not acquired de jure recognition from individual Western countries nor from the Paris Peace Conference (see Hent Kalmo's contribution in this volume). The Peace Treaty of Tartu was the first international treaty to refer, expressis verbis, to that principle, and therefore could be seen as a beginning of a process by which the idea of national self-determination would be transformed from a principle into a legal norm. ${ }^{12}$

From the perspective of colonial history, it is easy to understand why the Tartu Peace Treaty has acquired such an important position in the Estonian national identity. Despite the promise of the Peace of 1920, Estonia had to struggle throughout the $20^{\text {th }}$ century to maintain its autonomy against encroachments by the imperialist power in the East. Stalinist and post-Stalinist colonisation of Estonia from the 1940s to the 1980s was a traumatic experience,$^{13}$ and in the 1990s, Estonia was anxious lest the post-Cold War attempt to assert sovereignty against its former coloniser would be derailed just as the previous efforts were. It was symptomatic of the Estonian postcolonial outlook in the early 1990s that it defined itself through Russia, and therefore through the Tartu Peace Treaty, rather than through the Declaration of Independence of $1918 .{ }^{14}$ In this vein, the Tartu Peace Treaty was called the 'birth certificate' of Estonia - a phrase coined by President Lennart Meri but often repeated by other prominent politicians, most recently by President Kersti Kaljulaid. ${ }^{15}$

\footnotetext{
$12 \quad$ Lauri Mälksoo, "Which Continuity: The Tartu Peace Treaty of 2 February 1920, the Estonian-Russian Border Treaties of 18 May 2005, and the Legal Debate about Estonia's Statue in International Law", Juridica International 10 (2005), 144-149.

13 Aili Aarelaid-Tart, Cultural trauma and life stories, Doctoral dissertation (Helsinki: University of Helsinki, 2006).

14 Vahur Made, Eesti välispoliitika 100 aastat (Tallinn: Post Factum, 2019), 24.

15 "Vabariigi President Soome Vabariigi presidendi Martti Ahtisaari auks korraldatud pidulikul vastuvõtul 31. mail 1994 riigivisiidil Eesti Vabariiki", https://vp1992-2001. president.ee/est/k6ned/K6ne.asp?ID=4233 (24 March 2016). But Meri also used the 'birth certificate' image for the Declaration of Independence of 24 February 1918, "President of the Republic of Estonia in the Estonia Concert Hall on 24 February 1993", https://vp1992-2001.president.ee/eng/k6ned/K6ne.asp?ID=9487 (24 March 2016). "President Kaljulaid Tartu rahu 10o. aastapäeval: Tartu rahuleping oli, on ja jääb Eesti riigi sünnitunnistuseks", https://www.president.ee/et/meediakajastus/pressiteated/15799president-kaljulaid-tartu-rahu-10o-aastapaeeval-tartu-rahuleping-oli-on-ja-jaeaebeesti-riigi-suennitunnistuseks/index.html.
} 
From the Estonian perspective, the Tartu Peace Treaty is a litmus test of the willingness of Russia to come to terms with its colonial past and alleviate the existential fears of its former possession. In the early 1990s, when Estonian and Russian politicians were still very much on speaking terms, Estonian leaders were frank about their feelings of angst. In November of 1992, President Meri told Deputy Foreign Minister Vitali Churkin, when the latter took up the interests of Estonia's Russian-speaking minorities, that Estonia was afraid of the extinction of the entire Estonian nation, which explained the decision to re-establish the Republic on the basis of legal continuity, resting on the validity of the Tartu Peace Treaty. Meri, who was sympathetic toward the Russian case about minorities, admitted that Estonians would need to overcome the existential fear that underlined its nationalities policies, but this would necessarily take time. ${ }^{16}$

As Russia saw it - and probably still sees it today - Estonian fears were not Russia's fault, but the fault of the former Soviet Union (for the misdeeds of which Russia does not intend to apologise). Russian officials pointed out that Russia withdrew the former Soviet military garrison from Estonia by 1994 and had not threatened the country in any way. Russia even offered Estonia security guarantees that the latter rejected. ${ }^{17}$ Because Russia thought it had been sympathetic toward Estonia's quest for sovereignty, it declared surprise at Estonia's desire to join NATO. In 1995, Foreign Minister Yevgeni Primakov told the Estonian Foreign Minister Siim Kallas in no uncertain terms that from Moscow's point of view, accession to NATO was out of the question, and if Estonia persisted, Russia would have to take measures to defend its national interests. ${ }^{18}$ The Russian side was apparently unable or unwilling to comprehend that a Russian security guarantee was precisely the sort of thing that Estonia feared, and thinly veiled threats would drive the country even more certainly toward NATO membership (which Estonia achieved in 2004).

As to the question of the Tartu Peace Treaty, Russia apparently viewed it from the perspective of the status of all former administrative borders

\footnotetext{
16 "Meeting between President Lennart Meri and Vitali Churkin, 3 November 1992", 1992. aasta aruanded (memod), november-detsember, Archives of the Estonian Ministry of Foreign Affairs.

17 Loshchinin, "The Baltic States"; "Transcript of the meeting between Siim Kallas and Yevgeni Primakov in Petroskoi, 5 November 1995", 1995. aasta aruanded (memod), november-detsember, Archives of the Estonian Ministry of Foreign Affairs. About Yeltsin's unilateral offer of security guarantee, see Andres Kasekamp, "An uncertain journey to the promised land: The Baltic states' road to NATO membership", Journal of Strategic Studies 6-7 (43) (2020), 869-896 (873).

18 Meeting between Siim Kallas and Yevgeni Primakov, 5 November 1995.
} 
of the Soviet Union. Challenging one border would open the Pandora's box of all the USSR's internal borders that had become inter-state borders after 1991. ${ }^{19}$ However, the Russian position has been inconsistent on this point as well, as Moscow has violated those borders in Moldova, Georgia and most clearly in Ukraine, therefore the Russian attitude has been pragmatic rather than legalistic. ${ }^{20}$

What affected Russia's position regarding the Tartu Peace Treaty was the concern that by recognising the validity of the treaty, it could provide Estonia with grounds for claiming former Estonian territories east of the Narva River and in Petserimaa, and theoretically even for requesting compensation for property nationalised by the Soviet government in those lands. ${ }^{21}$ Estonia understood those concerns and by 1995 was willing to waive all claims to either territory or compensation. As a result of Estonia's flexibility, the two sides were able to complete negotiations in May of 2005 on a border treaty that included no reference to the Tartu Peace Treaty. In June of 2005, the Estonian Parliament ratified the Treaty. However, in September of 2005, President Vladimir Putin took an unprecedented step and signed an order rescinding Russia's signature of the border treaty. ${ }^{22}$

The incentive for Putin's decision was a declaration that the Estonian Parliament decided to add to the ratification law. The reasoning of some Estonian international law experts and legislators was that the issue of the border could be detached from the issue of the Tartu Peace Treaty without weakening the validity of the latter; however, in order to make it clear that the new border, based on the line drawn unilaterally by Stalin in 1944-45, did not weaken the validity of the rest of the Tartu Treaty, a parliamentary declaration to that effect was a sensible thing to do. ${ }^{23}$ For Russia, this proved to be a red flag. The truth is that Russian diplomats and politicians had warned Estonians repeatedly against precisely such announcements. In November of 1995, Primakov praised Estonians for abandoning territorial

\footnotetext{
19 Loshchinin, "The Baltic States".

20 Not frozen! The unresolved conflicts over Transnistria, Abkhazia, South Ossetia and Nagorno-Karabakh in light of the crisis over Ukraine, SWP Research Paper 9, ed. by Sabine Fischer (Berlin, 2016).

${ }_{21}$ "Briefing on the meeting between Siim Kallas and Yevgeni Primakov, 30 November 1995", 1995. aasta aruanded (memod), november-detsember, Archives of the Estonian Ministry of Foreign Affairs.

22 Kari Alenius, "The Estonian-Russian border negotiations: A prelude to the cyberattacks of 2007", European Conference on Cyber Warfare and Security (Academic Conferences International Limited, 2017), 17-23; Toomas Alatalu, "Geopolitics Taking the Signature from the Russian-Estonian Border Treaty (2005)", Baltic Journal of European Studies 3/2 (2013), 96-119.

23 Mälksoo, "Which Continuity".
} 
claims in official negotiations but complained about their annoying practice of 'attacking with your Tartu Peace from the flank'. ${ }^{24}$ Estonian government representatives had promised not to promote any declarations 'from the flank', but of course they could not give guarantees on behalf of the Estonian Parliament. The reasons for Russia's indignant reaction are still unclear, but it may well be that Moscow had hoped that the new border treaty would, in fact, invalidate the Tartu Peace Treaty entirely. This is precisely how Primakov understood it in 1995, voicing satisfaction that Estonians had eventually 'given up on territorial claims and on the Tartu Peace.'. As a matter of fact, only the first part of Primakov's statement was true.

Is there any chance for compromise? Professor Konstantin Khudoley argues in this volume that the example of the Tartu Peace Treaty has not lost its relevance in the $21^{\text {st }}$ century, as it can be taken as a model of how countries of different social systems can compromise without either side losing face. The way out of the current dilemma would be for Russia to confirm the continued validity of Article Two of the Tartu Peace Treaty, thus acknowledging the 'birth certificate' of independent Estonia, ${ }^{26}$ and for Estonia to accept that the Treaty on Basic Principles of Interstate Relations of 1991 and other modern-day treaties supersede much of the rest of the Tartu Peace Treaty. Unfortunately, one can agree with Khudoley that prospects for such a breakthrough in Estonian-Russian relations are slim, considering the tensions that have built up between Russia and the West more generally. This time, Estonia will most probably not act unilaterally, as it did in 1919-2020, to come to a special arrangement with Russia. Therefore, the post-colonial situation in Estonian-Russian relations - Estonia continuing to define itself through its former colonial master, and Russia unwilling to admit and renounce the colonial ways of its Soviet predecessor - will not end any time soon.

KaArel Piirimäe is Associate Professor at the Institute of History and Archaeology, University of Tartu, and Researcher at the Centre for European Studies, University of Helsinki.*

Kaarel Piirimäe on kaasprofessor Tartu Ülikooli ajaloo ja arheoloogia instituudis ja teadur Euroopa uuringute keskuses Helsingi ülikoolis.*

24 Meeting between Siim Kallas and Yevgeni Primakov, 5 November 1995.

25 Ibid.

${ }_{26}$ The truth is that Russia has never said that Article Two was invalid after signing (from 1920 to 1940), however it has maintained that the Tartu Peace Treaty as such was a historic document only. I thank Hent Kalmo for this remark.

* Correspondence/ Kirjavahetus: Ajaloo ja arheoloogia instituut, Tartu Ülikool, Jakobi 2, 51003, Eesti. E-post: kaarel.piirimäe@ut.ee 